\title{
DIAGNOSTICS OF WORKPIECE SURFACE CONDITION BASED ON CUTTING TOOL VIBRATIONS DURING MACHINING
}

\author{
Jerzy Józwik', Dariusz Mika² \\ 1 Department of Production Engineering, Mechanical Engineering Faculty, Lublin University of Technology, \\ Nadbystrzycka 36, 20-816 Lublin, Poland, e-mail: j.jozwik@pollub.pl \\ 2 Center for the Study of Engineering, Institute of Technical Sciences and Aviation, The State School of Higher \\ Education in Chelm, Depułtycze Królewskie 55, 22-100 Chelm, Poland, e-mail: dmika@pwsz.chelm.pl
}

Received: 2015.04 .16

Accepted: 2015.05.08 Published: 2015.06.01

\begin{abstract}
The paper presents functional relationships between surface geometry parameters, feedrate and vibrations level in the radial direction of the workpiece. Time characteristics of the acceleration of cutting tool vibration registered during $\mathrm{C} 45$ steel and stainless steel machining for separate axes $(\mathrm{X}, \mathrm{Y}, \mathrm{Z})$ were presented as a function of feedrate $f$. During the tests surface geometric accuracy assessment was performed and $3 \mathrm{D}$ surface roughness parameters were determined. The $S z$ parameter was selected for the analysis, which was then collated with RMS vibration acceleration and feedrate $f$. The $S z$ parameter indirectly provides information on peak to valley height and is characterised by high generalising potential i.e. it is highly correlated to other surface and volume parameters of surface roughness. Test results presented in this paper may constitute a valuable source of information considering the influence of vibrations on geometric accuracy of elements for engineers designing technological processes.
\end{abstract}

Keywords: vibration, diagnostics, machining, turning, surface geometric structure, roughness parameters.

\section{INTRODUCTION}

Despite tremendous progress in the construction of both machine tools and cutting tools, effective methods of eliminating (minimising) vibration in machining are yet to be found $[1,3$, $4,7,11,12]$. It particularly concerns the process of machining flexible objects and those susceptible to heat (i.e. thin-walled parts and long, slender rollers) $[4-6,8,9,15]$ as well as machining with the use of highly flexible tools (mainly of high overhang) $[1,10]$. The analysis of literature $[4,5,12,15]$ shows that defects caused by elastic strains are of high importance, as far as the accuracy of machining is concerned, and they constitute from 20 to $80 \%$ of total machining error. While machined, low-stiffness parts generate vibration, their machining, however, cannot be avoided [5, 8, 15]. A significant group of parts used in the aviation industry can serve as an ex- ample of such objects. Irrespective of increasing stiffness of machine tools and modern materials used for main bodies and other parts of machine tools (having high capacity for dampening vibration) as well as precise tools and holders, still, vibration has a considerable influence on constituting the dimensional and shape characteristics manufactured parts $[2,3]$. The necessity to avoid vibration, especially self-induced one, usually enforces reduction of technological parameters of machining, which does not always seem the solution to a problem and is not economically viable [15]. In the process of machining, vibration has a number of sources, the principal of which are the force input, kinematic input and inertial input $[3,4,7,11,12]$. As a result of self-induced vibration while machining, almost periodic shape defects occur. This kind of vibration in the machine tool-clamp-object-tool system results from the oscillation of friction force and machining 
force values as well as forces responsible for transferring energy from propulsion into the machine tool-clamp-object-tool system. Vibration occurrence can be an outcome of multiple factors such as machining parameters, type of material and shape of machined object, the structure of a tool and its fastening as well as the steadiness of a machine tool itself. It has a negative influence on metal machining and seems particularly undesirable while finishing surfaces. What occurs as a result is high surface roughness, faster wear of a cutting blade and a high frequency noise which can be harmful to workers. Vibration occurs as a result of: inaccurate balancing of machine tool rotary parts or a revolving object being machined, intermittent character of the process of machining (i.e. consecutive use of a cutting blade while milling or a broach while broaching), kinematic transmission defects (i.e. graduation errors or eccentric performance of cutting blades in relation to the wheel rotation axis which trigger the appearance of periodic forces being transferred to machine tool bearings and guideways), external vibration (i.e. when another machine generating strong vibration works nearby). One more source of vibration can be a physical process of machining itself [1-12].
Vibration identification can be carried out with the use of contact sensors (i.e. accelerometers $<$ acceleration sensors $>$ ), non-contact laser techniques (i.e. laser vibrometers, laser sensors) as well as vision methods facilitating movement analysis (i.e. using fast vision cameras and a PONTOS system belonging to GOM). Examples of such measurement systems and their practical application can often be found in scientific literature [13-16].

\section{METHODOLOGY}

Diagnostic assessment of surface geometry after machining medium carbon steel $\mathrm{C} 45$ and stainless steel based on tool vibration measured during the machining process was the subject of this study. Rollers $d_{w}=50 \mathrm{~mm}$ in diameter and $l=200 \mathrm{~mm}$ in length served as workpiece. The research was conducted in The Center for the Study of Engineering in The State School of Higher Education in Chelm with the use of a CNC CTX 310 eco machine. The tests were conducted for several machining parameters collated in Table 1 and the test bed setup is presented in Figure 1.

Table 1. Technological machining parameters

\begin{tabular}{|c|c|c|c|c|c|}
\hline Material & \multicolumn{5}{|c|}{ Feed rate, $f[\mathrm{~mm} / \mathrm{rev}]$} \\
\hline \multirow{2}{*}{ Steel C45 } & 0.1 & 0.2 & 0.3 & 0.4 \\
\cline { 2 - 6 } & \multicolumn{5}{|c|}{$v_{c}=250 \mathrm{~m} / \mathrm{min}$} \\
\hline \multirow{2}{*}{ Stainless steel } & 0.1 & 0.2 & 0.3 & 0.4 \\
\cline { 2 - 5 } & \multicolumn{3}{|c|}{$v_{c}=280 \mathrm{~m} / \mathrm{min}$} \\
\hline
\end{tabular}

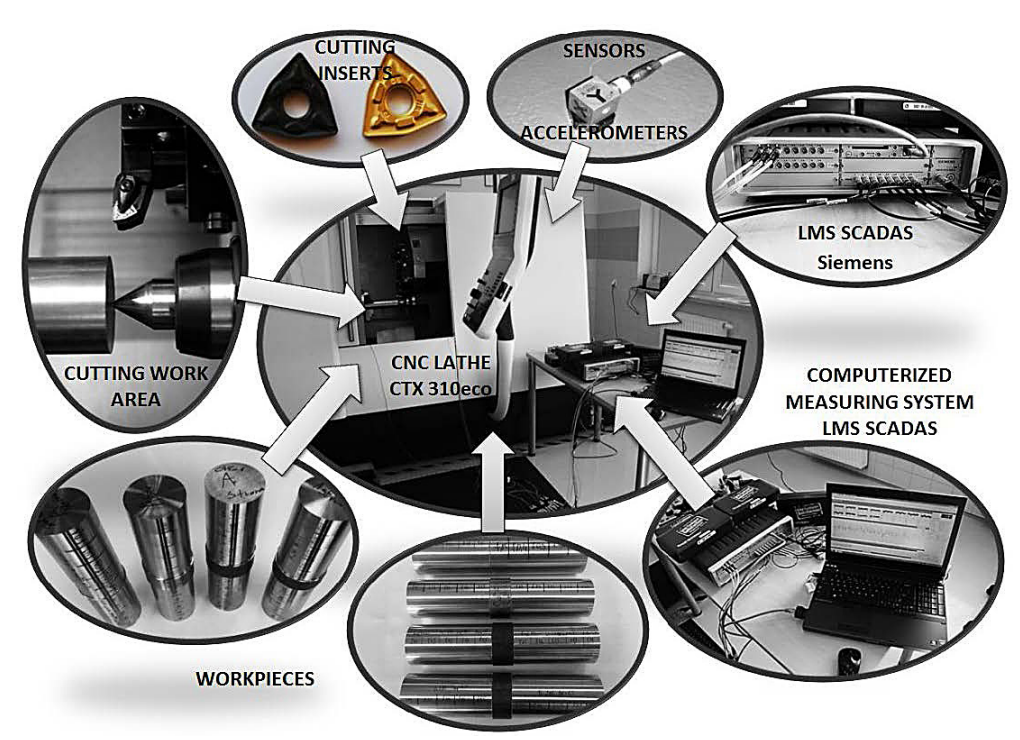

Fig. 1. Test stand; CTX 310 eco CNC, Coro Turn RC DWLNL 2020K08 rigid clamp, WNMG 0804 08-PM 4225, WNMG 0804 08-MR 2025 inserts for turning 
Tools used for the study were turning tools with interchangeable inserts dedicated to materials used as samples in the tests. A WNMG 0804 08-PM 4225 insert was used in the case of $\mathrm{C} 45$ steel and for the stainless steel a WNMG 0804 08-MR 2025 insert was applied. The inserts were placed in a Coro Turn RC DWLNL 2020K08 rigid clamp. Siemens MS Scadas data acquisition hardware was used for recording vibration in the process. Piezo-electric tri-axis vibration sensor PCB Piezotronic was used in the research. Experimental tests were repeated four times for each set of machining parameters with the aim of assessing repeatability of measurements. The surface analysis was conducted using the $S z$ parameter for 3D surface roughness analysis, which is defined as 10-point surface height. The surface geometry of the machined workpiece is rather complex, therefore, its analysis requires advanced measurement tools. An example of 3D surface structure after machining is shown in Figure 2.

Additionally, the $S z$ parameter was included in the tests due to a distinct connection to the remaining parameters measured. The $S z$ parameter provides information on the height of irregularity of surface and is resistant to random peaks and valleys along the sample. The parameter also demonstrated a clear correlation with $S a$ and $S q$ parameters based on the character of surface ordinates distribution. $S z$ parameter seems to be characterised by great generalising properties (is strongly correlated with other surface and volumetric parameters). Alicona IF was used for the measurement of 3D surface roughness parameters.

\section{RESULTS AND ANALYSIS}

\section{Vibration levels and their influence on stereometry during C45 steel machining}

In the course of the conducted tests, time history of cutting tool vibration acceleration during machining in three perpendicular directions (X, $\mathrm{Y}, \mathrm{Z})$ defined in Figure 3 were registered. A coordinate system oriented in this manner applies to vibration measurement and results from the position of the sensor and the tool in the turret.

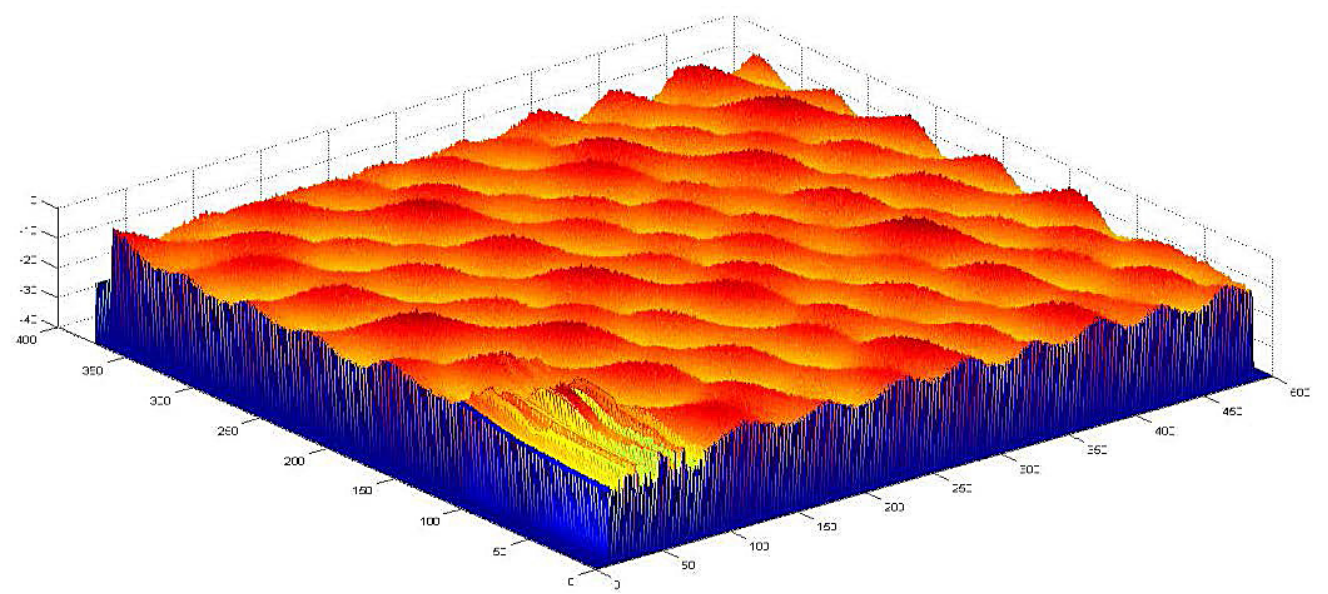

Fig. 2. An example of 3D surface structure after machining [17]

a)

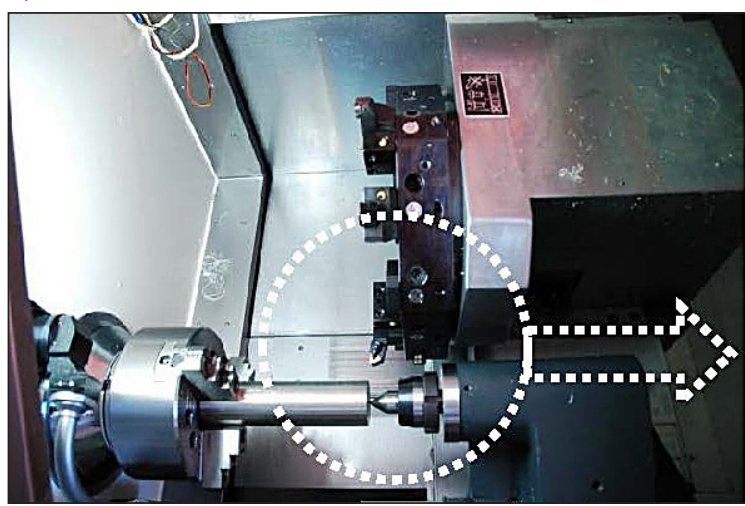

b)

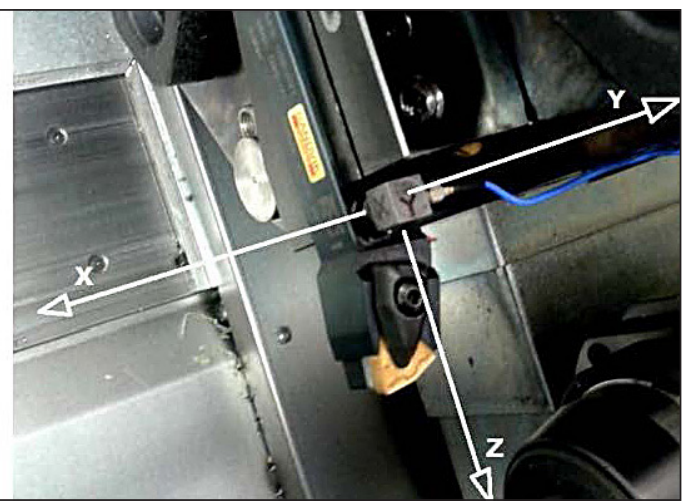

Fig. 3. Cutting stand: a) CNC working space, b) vibration directions measurement during turning 
The system is independent of commonly applied numerically controlled axis positioning system of the analysed machine.

Figures 4-6 are a graphic representation of selected test results. Exceptionally interesting results were obtained in the $\mathrm{Z}$ axis direction (thrust force direction), where increasing values of the force should result in decreasing vibrations. Figure 4 shows time history of the cutting tool vibration acceleration during $\mathrm{C} 45$ steel machining in axes $\mathrm{X}, \mathrm{Y}, \mathrm{Z}$ defined in Figure 3. Based on the registered vibrations time history, it was found that feedrate demonstrates repeated, unequivocal influence on vibrations amplitude. Vibration increase has been observed both during machining high-quality constructional steel C45
(Figs. 4-5) and stainless steel (Figs. 8-9). Figure 5 presents results of cutting tool vibration timefrequency analysis in the form of spectrograms, for the $\mathrm{X}, \mathrm{Y}$ and $\mathrm{Z}$ axes respectively. The spectrograms presented in the form of coloured maps display areas of accelerated vibrations of specific amplitudes at specific frequencies, derived from time history of vibration acceleration registered in tests. Figure 6 depicts distribution of energy density of the cutting tool vibration signal during C45 steel machining, with a characteristic peak of vibration energy concentration at approximately $3.7 \mathrm{kHz}$. The peak (Fig. 6) was detected for all measured axes and equals to maximum vibrations value $30 \mathrm{~dB}$. The characteristic peaks at 3.7 $\mathrm{kHz}$ are a result of self-induced vibrations.
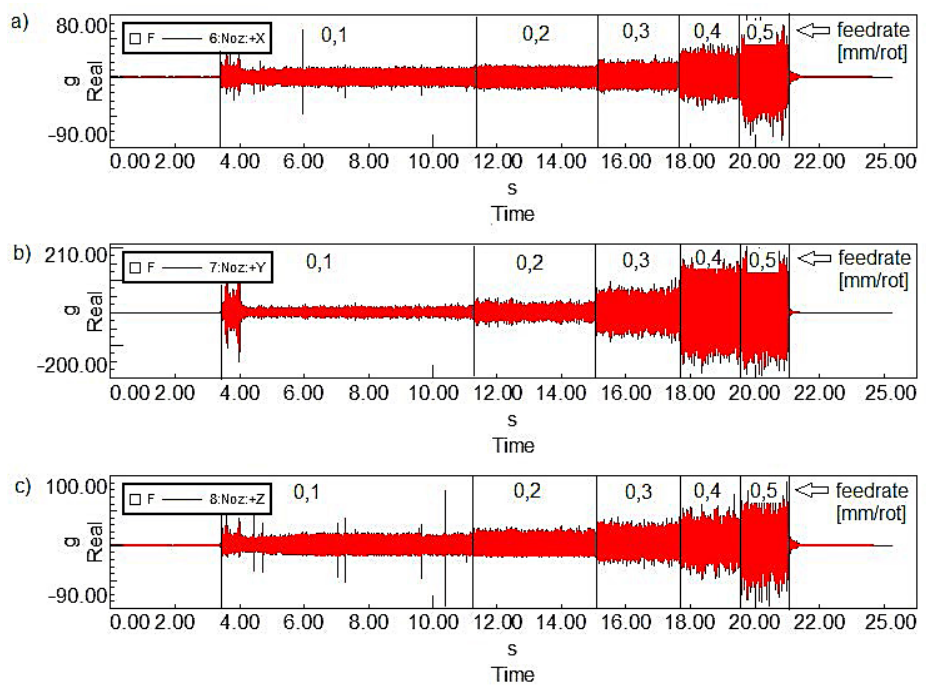

Fig. 4. Time history of cutting tool vibration during $\mathrm{C} 45$ steel machining for: a) $\mathrm{X}$ axis spectrogram, b) $\mathrm{Y}$ axis spectrogram, c) $\mathrm{Z}$ axis spectrogram
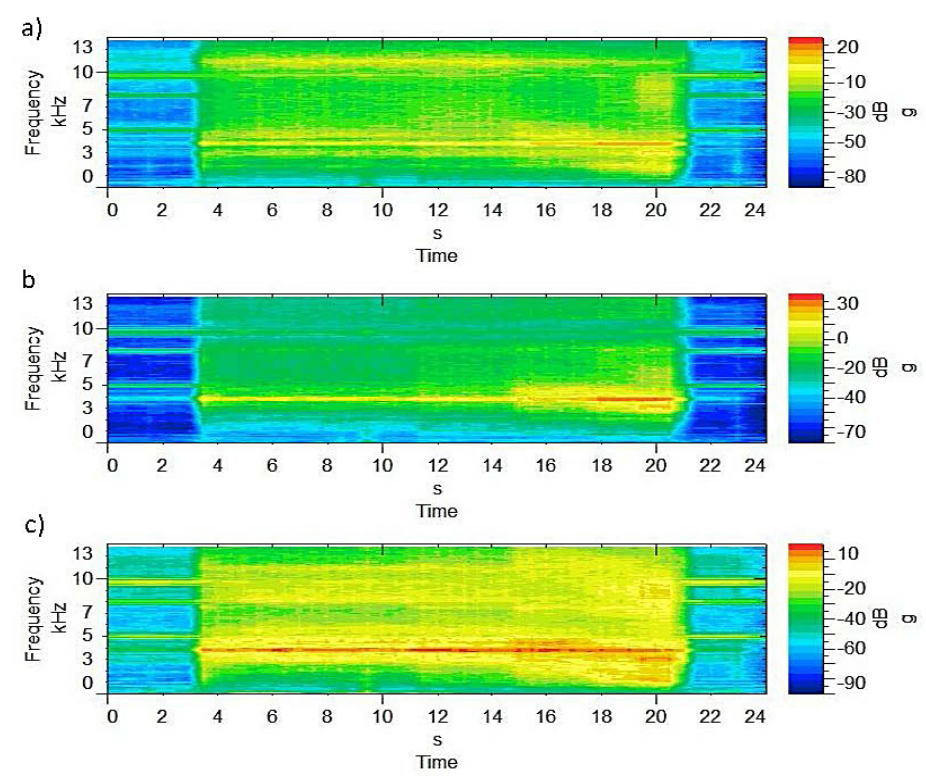

Fig. 5. Results of cutting tool vibration time-frequency analysis during machining C45 steel:

a) $\mathrm{X}$ axis spectrogram, b) $\mathrm{Y}$ axis spectrogram, c) $\mathrm{Z}$ axis spectrogram 


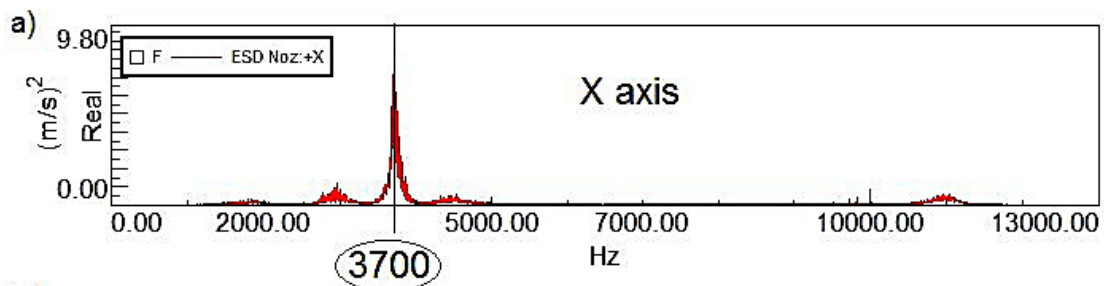

b)
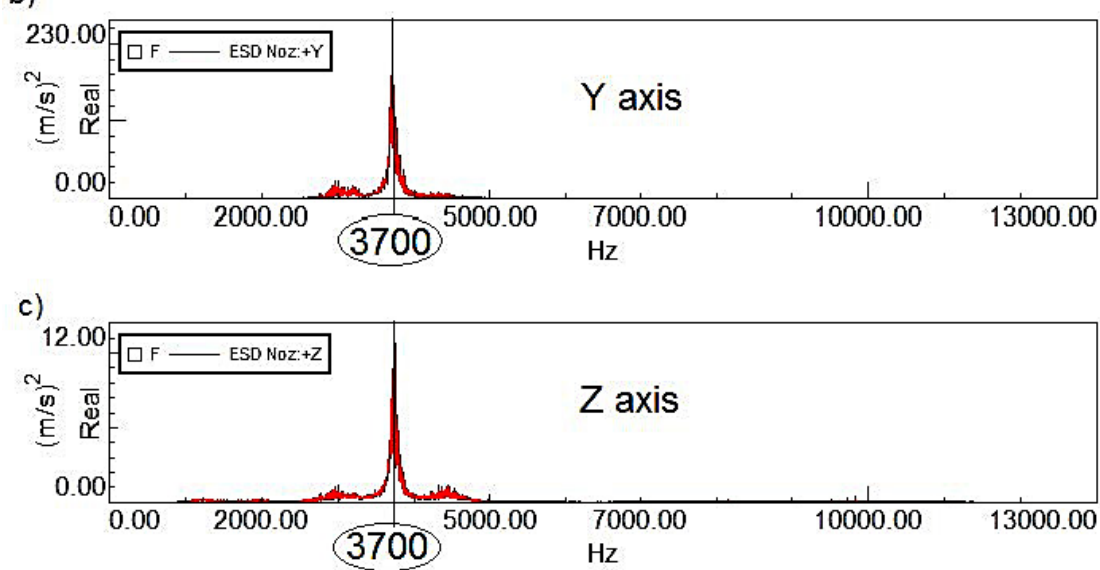

Fig. 6. Distribution of energy density of cutting tool vibration signal during C45 steel machining: a) for X axis, b) for $\mathrm{Y}$ axis, c) for $\mathrm{Z}$ axis

All conducted tests indicate that the $\mathrm{Y}$ axis, which is parallel to the cutting speed vector, is characterised by highest vibration values. This is caused by the highest value of the cutting force main component acting in that direction. The force function of the main component caused the highest value of the registered amplitude. In the case of C45 steel comparable vibration values were observed for both $\mathrm{X}$ (along the feedrate direction) and $\mathrm{Z}$ axis (thrust force direction). Vibrations in the $\mathrm{Z}$ axis (thrust force) direction seem interesting with regards to post machining surface condition. In the case of C45 steel vibrations in this axis are concentrated mainly at $3.7 \mathrm{kHz}$ and are equal to $10 \mathrm{~dB}$ (with highest federate value $f=0.5 \mathrm{~mm} / \mathrm{rev}$ ). Table 2 collates the surface stereometry measure- ment results described with the $3 \mathrm{D}$ roughness parameter $S z$. Vibrations were expressed using the RMS vibration acceleration expressed in $g$ (grams). Table 2 indicates that in the case of C45 steel, surface roughness $S z$ increases as a function of feedrate from $14.98 \mathrm{~mm}$ (with $f=$ $0.1 \mathrm{~mm} / \mathrm{rev}$ ) up to $37.81 \mathrm{~mm}$ (with $f=0.5 \mathrm{~mm} /$ rev) (Fig. 7a). An almost linear RMS vibration acceleration increase $14.98 \mathrm{~g}$ to $37.81 \mathrm{~g}$ implies an increase in surface roughness. It needs to be emphasised that increasing federate $f$ values significantly influence roughness values.

Figure $7 \mathrm{~b}$ implies various $S z$ surface roughness increase rates as a function of feedrate and RMS vibration acceleration. Test results have demonstrated a linear correlation of the analysed parameters as a function of feedrate $f$.

Table 2. Measurement results for specified machining parameters of C45 steel machining

\begin{tabular}{|c|c|c|c|c|c|}
\hline Machining parameters & \multicolumn{5}{|c|}{ C45 steel } \\
\hline Feedrate, $f[\mathrm{~mm} / \mathrm{rev}]$ & 0.1 & 0.2 & 0.3 & 0.4 & 0.5 \\
\hline RMS vibration acceleration, [g] & 5.3 & 7.6 & 9.2 & 9.6 & 11 \\
\hline Roughness, $S z[\mu \mathrm{m}]$ & 14.98 & 20.05 & 23.23 & 30.39 & 37.81 \\
\hline Cutting speed, $v_{c}[\mathrm{~m} / \mathrm{min}]$ & \multicolumn{5}{|c|}{$v_{c}=250 \mathrm{~m} / \mathrm{min}$} \\
\hline \multicolumn{6}{|c|}{ Stainless steel } \\
\hline Feedrate, $f[\mathrm{~mm} / \mathrm{rev}]$ & 0.1 & 0.2 & 0.3 & 0.4 & 0.5 \\
\hline RMS vibration acceleration, [g] & 3.4 & 3.6 & 5.8 & 44.1 & 92.3 \\
\hline Roughness, $S z[\mu \mathrm{m}]$ & 34.61 & 38.23 & 28.58 & 43.95 & 37.45 \\
\hline Cutting speed, $v_{c}[\mathrm{~m} / \mathrm{min}]$ & \multicolumn{5}{|c|}{$v_{c}=280 \mathrm{~m} / \mathrm{min}$} \\
\hline
\end{tabular}


a)

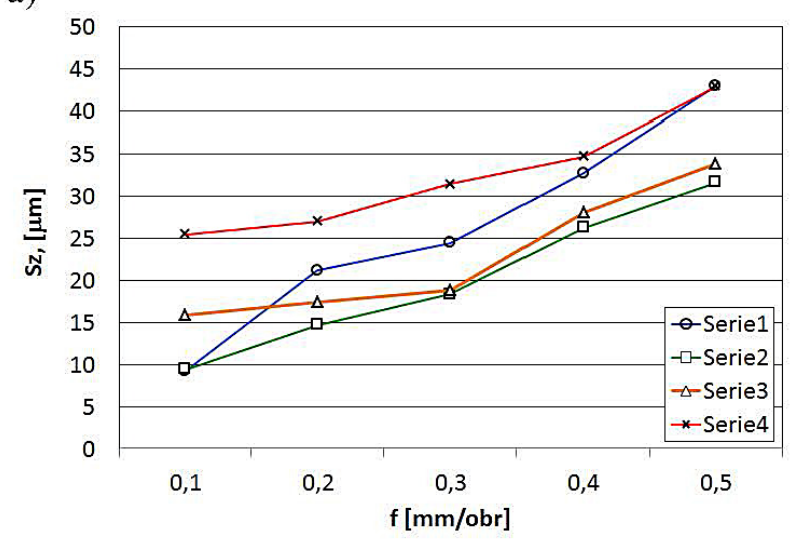

b)

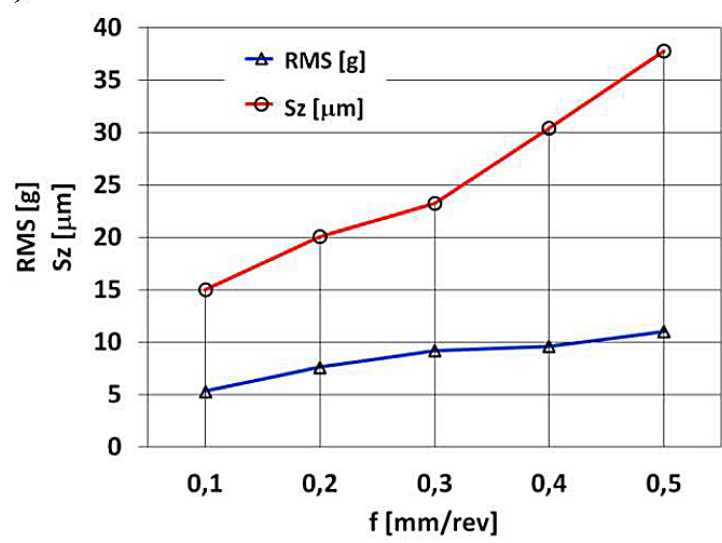

Fig. 7. $S z$ and RMS vibration acceleration parameters during $C 45$ steel machining as a function of feedrate $f$ : a) $S z$ value changes over 4 measurements, b) comparison of $S z$ and RSM vibration acceleration

\section{Evaluation of vibration values and their influence on surface stereometry during stainless steel machining}

Contrary to the results presented in literary sources, also stainless steel (similarly to C45) demonstrated growing changes in vibration acceleration amplitude as a function of feedrate, for all measurement axes defined in Figure 3, namely X, $\mathrm{Y}$ and $\mathrm{Z}$ (Figs. 8-9). Figure 8 shows time history of cutting tool vibration acceleration registered during stainless steel machining in three analysed axes $\mathrm{X}, \mathrm{Y}$ and $\mathrm{Z}$. During the tests it was discovered that vibrations in the direction $(\mathrm{Z})$ of the thrust force prove to influence the surface geometric structure after machining to the largest extent.

Figure 9 presents results of time-frequency analysis of cutting tool vibration acceleration dur- ing stainless steel machining, whereas Figure 10 shows distribution of energy density of the cutting tool vibration acceleration signal. In the case of stainless steel the vibration acceleration amplitude in the $\mathrm{Z}$ axis direction was clearly higher compared with the $\mathrm{X}$ axis direction and comparable with the vibration acceleration across the $\mathrm{Y}$ axis. Based on the stainless steel tests, distinctly higher level of vibration was measured compared to high-quality steel C45 (Fig. 8). Maximum values were observed across the $\mathrm{Y}$ axis and equalled approximately $50 \mathrm{~dB}$ at $3.6 \mathrm{kHz}$ and $f=0.5 \mathrm{~mm} /$ rev. The conducted time-frequency analysis of the cutting tool vibration signal during stainless steel machining revealed a characteristic peak at 3.6 $\mathrm{kHz}$ and for $10.6-10.7 \mathrm{kHz}$ of the $\mathrm{X}$ axis.

Compared with $\mathrm{C} 45$, the peak found during stainless steel tests occurs at slightly lower fre-

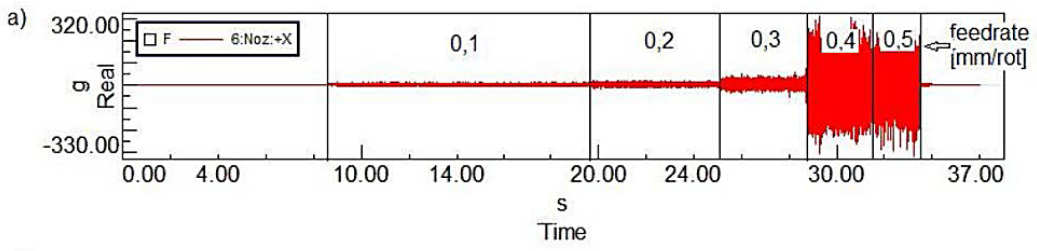

b)
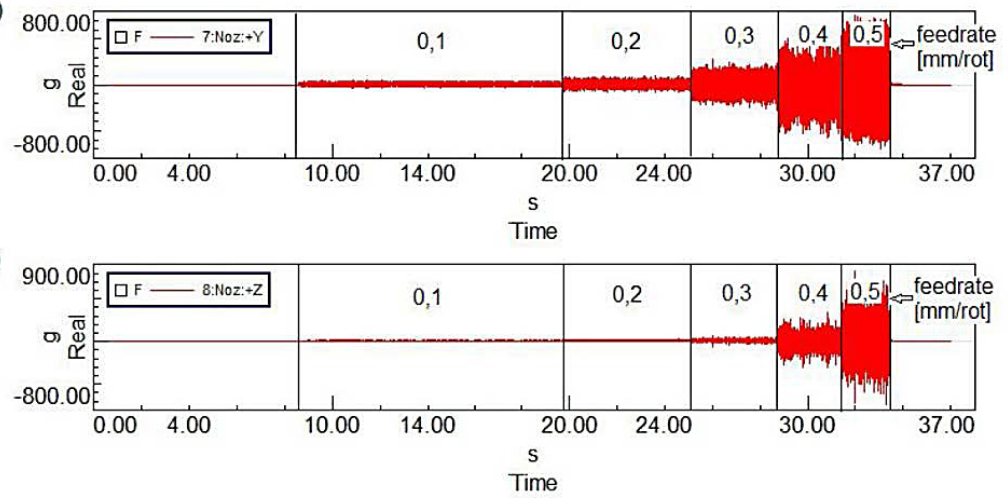

Fig. 8. Time history of cutting tool vibration acceleration registered during stainless steel machining for:

a) $\mathrm{X}$ axis, b) $\mathrm{Y}$ axis, c) $\mathrm{Z}$ axis 
a)

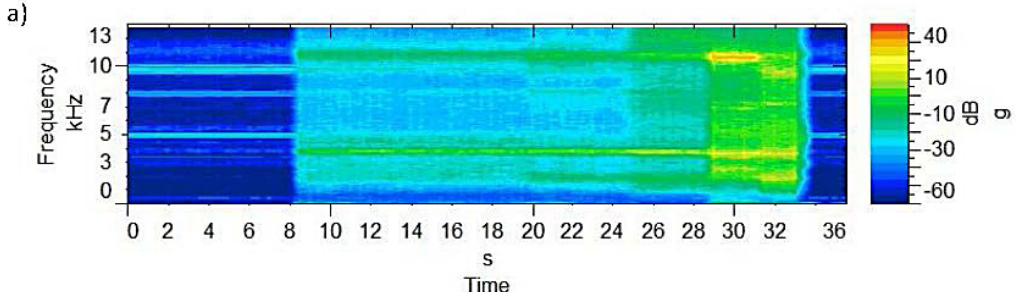

b

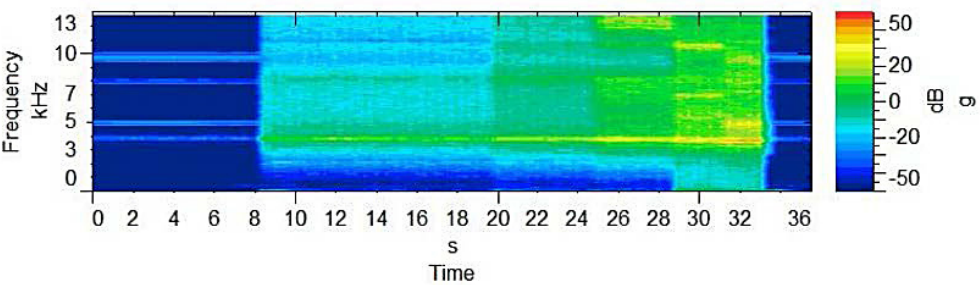

c)

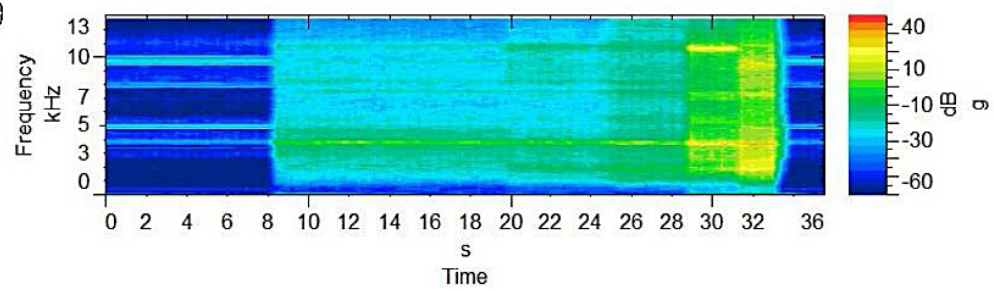

Fig. 9. Results of cutting tool vibration time-frequency a nalysis during machining stainless steel:

a) $\mathrm{X}$ axis spectrogram, b) $\mathrm{Y}$ axis spectrogram, c) $\mathrm{Z}$ axis spectrogram

a)

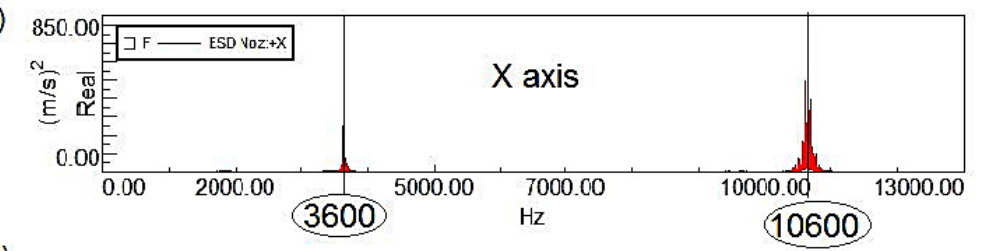

b)

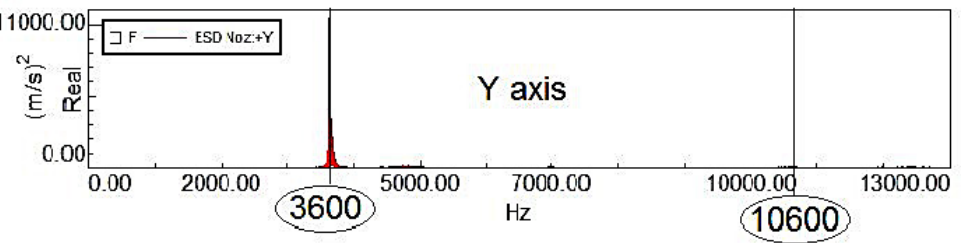

c)

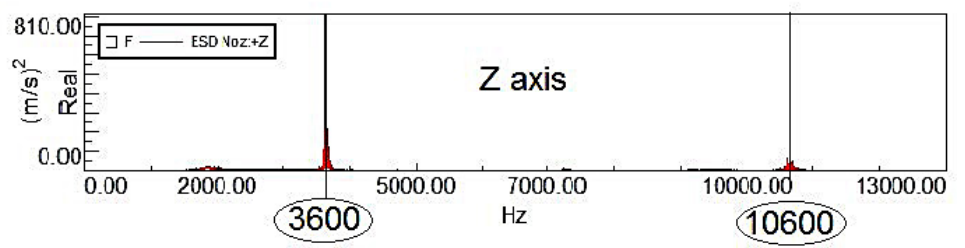

Fig. 10. Distribution of vibration signal density energy during stainless steel machining:

a) for $\mathrm{X}$ axis, $\mathrm{b}$ ) for $\mathrm{Y}$ axis, c) for $\mathrm{Z}$ axis

quency equal $3.6 \mathrm{kHz}$ (presenting highest value for the $\mathrm{Y}$ axis at $50 \mathrm{~dB}$ ). In the $\mathrm{X}$ axis (along the feedrate direction) an additional peak can be observed at approximately $10.6-10.7 \mathrm{kHz}$ which equals $40 \mathrm{~dB}$, also visible for the $\mathrm{Z}$ axis (the thrust force direction) mainly with $f=0.4$ equal to approximately $20 \mathrm{~dB}$. In the case of stainless steel, the main peak was observed at $3.5 \mathrm{kHz}$ and is equal to $40 \mathrm{~dB}(f=0.5)$ and $10.6-10.7 \mathrm{kHz}$ amounting to $20 \mathrm{~dB}(f=0.4)$.
The observed peaks are most likely a result of self-induced vibration.

In the surface stereometry tests, the obtained surface roughness parameters presented considerably higher values than in the case of C45 steel (comparison of Fig. 7a and Fig. 11a). The $S z$ spatial roughness adopted maximum values amounting to $50-60 \mathrm{~mm}$ (Fig. 11a) in partial tests. Figure 11 a indicates a great scatter of $S z$ values and a lack of a distinct tendency in each test run, which 
a)

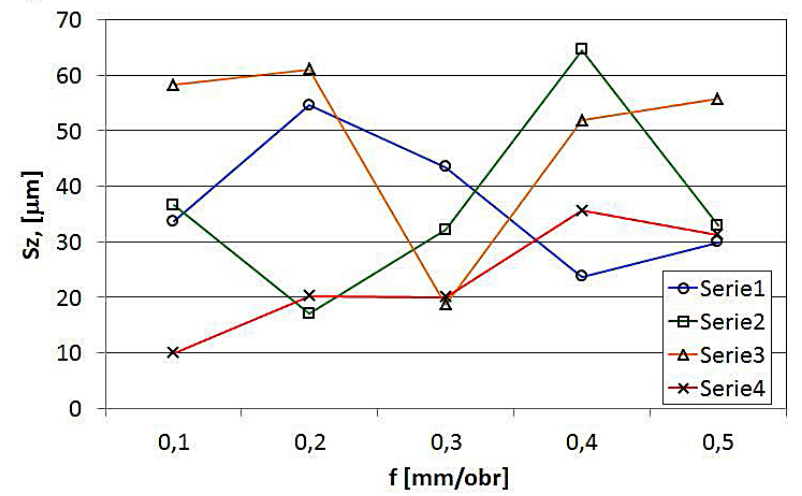

b)

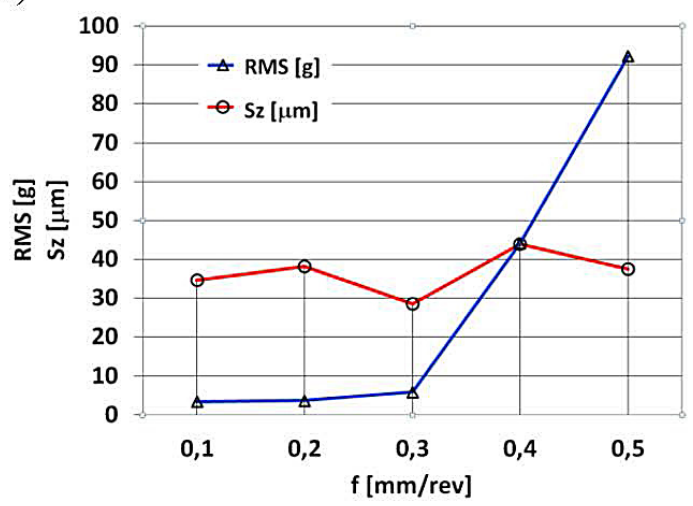

Fig. 11. $S z$ and RMS vibration acceleration parameters during stainless steel machining as function of feedrate $f$ : a) $S z$ value changes over 4 measurements, b) comparison of $S z$ and RSM vibration acceleration

is completely different from the one observed for C45 steel (Fig. 7a). Lack of roughness change tendency is partly a result of slight changes in RMS cutting tool vibration acceleration within a range of feed values $f(0.1-0.3 \mathrm{~mm} / \mathrm{rev})$. The vibration system is also relatively insensitive to changes in feed rate. Only highest values $f=0.4-0.5 \mathrm{~mm} / \mathrm{rev}$ induced a sudden surge in RMS vibration acceleration values (Fig. 11b).

\section{CONCLUSIONS}

Based on conducted experimental tests a linear dependence of RMS vibration acceleration and $\mathrm{Sz}$ roughness of the C45 constructional carbon steel workpiece as a function of $f$ feed can be observed. A changing intensity in roughness and RSM vibration acceleration increase as a function of $f$ (different slopes of a curve depicting the discussed parameters - different slopes of a straight line) was found. Nevertheless, the obtained characteristics are unambiguous, linear and easily forecasted. Simultaneously, a strong scatter of results was observed for 3D structure of the workpiece surface $S z$ in stainless steel samples (as opposed to C45 steel). A lack of an increasing trend for RMS vibration acceleration as a function of $f$ was identified for the $f$ range amounting to $f=0.4-0.5 \mathrm{~mm} / \mathrm{rev}$ and a significant increase in RMS vibration acceleration for higher $f$ values $(f=0.4-0.5 \mathrm{~mm} / \mathrm{rev})$. The analysis of energy density distribution of the cutting tool vibrations signal during C45 steel machining and stainless steel demonstrated characteristic peaks at frequencies equal to $3.7 \mathrm{kHz}$ (for $\mathrm{C} 45 \mathrm{steel}$ ) and $3.6 \mathrm{kHz}$ and $10.6-10.7 \mathrm{kHz}$ (for stainless steel), which are a result of self-induced vibrations. Much higher val- ues of vibration amplitude were revealed during stainless steel machining, which seems to result from material properties (mainly strength) as well as stainless steel machining resistance. This work presents graphic representation of the time-frequency analysis of cutting tool vibrations during C45 steel and stainless steel machining, which allow easy identification of amplitude and frequency vibration components dominant in the time history. Workpiece surface condition diagnostics based on cutting tool vibration is a relatively effective method when active machining process monitoring is concerned. However, it requires advanced measuring tools and programmes for the analysis of the obtained vibrations spectra and for estimating reliable parameters. Collecting and storing the data in a knowledge base may allow a quick and precise measurement of the surface state at the stage of production system design. Consequently, it would allow effective development of a technology which would minimise the number of defective units in production. The conducted tests prove a dependence of geometric characteristics of surface parameters on vibrations level. The conducted tests also indicate the need of further analysis of other factors influencing surface roughness, which need to be taken into consideration in modelling and developing diagnostic systems with the aim of separating their influence on surface geometry and vibration levels.

\section{REFERENCES}

1. Galewski M., Nadzorowanie drgań podczas frezowania szybkościowego smukłymi narzędziami z wykorzystaniem zmiennej prędkości obrotowej wrzeciona. Rozprawa doktorska, Gdańsk, 2007. 
2. Józwik J., Kobyłka M., Badanie wpływu parametrów geometrycznych kieSzeni prostokątnej oraz warunków realizacji procesu skrawania na drgania podczas frezowania trochoidalnego. Postępy Nauki i Techniki, 8, 2011, 37-44.

3. Jemielniak K., Wypysiński R., Symulacja numeryczna drgań samowzbudnych - przegląd metod, możliwości i potencjalnych korzyści, Mechanik 8-9, 2013, 43-56.

4. Józwik J., Modelowanie ugięć sprężystych przedmiotów obrabianych $\mathrm{w}$ procesie skrawania toczeniem, Postępy Nauki i Techniki, 8, 2011, 183-191.

5. Józwik J., Lipski J., Błędy obróbki skrawaniem i ich prognozowanie z wykorzystaniem Sztucznych sieci neuronowych. Wyd. Politechnika Lubelska, Lublin 2014.

6. Józwik J., Filipiak P., Analysis of feedrate correction influence on corner radius errors of workpieces during milling, Journal of Machine Engineering, 9(1), 2009, 66-77.

7. Kęcik K., Rusinek R., Warminski J., Modelling of high-speed milling process with frictional effect, Journal of Muti-body Dynamics, Proceedings of the Institution of Mechanical Engineers Part K, 1(1), 2013, 3-11.

8. Kuczmaszewski J., Pieśko P., Wear of milling cutters resulting from high silicon aluminium alloy cast AISi21 CuNi machining. Maintenance and Reliability, 1(16), 2014, 37-41.

9. Kuczmaszewski J., Pieśko P., Włodarczyk M., Milling of thin-walled aviation elements - analysis of the model and verification tests, [In:] $6^{\text {th }}$ International Conference - Supply on the Wings-Aero- space - the Global Innovation Driver, Frankfurt Germany, 2011, 25-25.

10. Pieśko P., Zagórski I., Analiza dokładności obróbki frezami trzpieniowymi o zmiennej Sztywności tulei cienkościennych wykonanych z stopu AlMn1. [W:] A. Świć (red.) Innowacyjne procesy technologiczne, Lublin 2011, 33-46.

11. Rusinek R., Vibrations in cutting process of titanium alloy. Maintenance and Reliability, 3, 2010, $48-55$.

12. Rusinek R. Warmiński J., Szabelski K., Drgania nieliniowe $\mathrm{W}$ procesie skrawania toczeniem. Monografia. IZT Sp. z.o., Lublin 2006.

13. Słodki B., Zębala W., Stanowisko do rejestracji obrazów szybkozmiennych w procesach skrawania. [W:] H. Latoś (red.) Obróbka skrawaniem zaawansowana technika. Wyd. Uczelniane Uniwersytetu Technologiczno-Przyrodniczego, Bydgoszcz 2009, 215-220.

14. Szydłowski M., Powałka B., Berczyński S., Stanowisko badawcze do wizyjnej inspekcji powierzchni obrobionej. Mechanik 8-9, 2013, 439-446.

15. Zębala W., Minimalizacja błędów obróbki przedmiotów cienkościennych. Inżynieria Maszyn, 15(3), 2010, 45-54.

16. Józwik J.: Analiza ruchu podczas obróbki frezarskiej przedmiotów cienkościennych z zastosowaniem wizyjnego systemu pomiarowego 3D. Mechanik, 8-9, 2014, 551-562.

17. Kacalak W., Szafraniec F., Kunc R. Remelska H.: Zastosowanie teorii fraktali do tworzenia i wizualizacji powierzchni o określonej topografii. [W:] Podstawy i technika obróbki ściernej, Łódź 2010. 